\title{
Application of Lean Manufacturing Methods to Streamline the Welding Line
}

Michal Bucko, Vladimira Schindlerova, Ivana Sajdlerova

Faculty of Mechanical Engineering, VSB - Technical University of Ostrava. 17. Listopadu 2172/15, 70800 Ostrava-Poruba. Czech Republic. E-mail: michal.bucko@vsb.cz, vladimira.schindlerova@vsb.cz, ivana.sajdlerova@vsb.cz

This paper deals with the use of lean manufacturing methods to streamline the welding line in the automotive industry. The automotive industry is constantly developing and innovating its production environments and technology because of growing competition on the market and customer demands. Current trends of car makers include pressure to reduce costs and increase production efficiency. With the commencement of new technologies, the production lines began to innovate and the production cycle began to constantly accelerate.

The paper deals with the reconstruction of the welding line, which produces parts for the rear axle of a compact SUV. The case study aims to identify bottlenecks and set innovation plans and their evaluation in possible implementation. In the paper, lean manufacturing methods are applied in order to determine the ideal solution for ensuring the quality and ensuring the efficiency of the production line, leading to cost reduction. Through these innovations and modernizations, the company will be heading for digitalisation that changes the core of the industry.

Keywords: Lean Manufacturing, Optimization, Automotive, Production Line, Welding

\section{Introduction}

Companies are constantly striving to upgrade their production by finding bottlenecks to improve their market position in terms of competitiveness. The deployment and innovation of automated production lines is essential both for labor shortages and for productivity and quality. The grouping of precision, continuity and speed - that might be the basic definition of a production line. Many years have passed since the introduction of the first production line by Henry Ford in 1913. However, it is important to mention that the fundamental principle remains the same, namely that the product is to go to the worker, not the worker to the product. Therefore, a methodology that contributes to reduction of cost and downtime is desirable. In the automotive industry, a combination of welding, painting and assembly lines can be found. It's just the welding lines (Fig. 1) that represent one of the key production lines in the automotive industry, because welded basic constructions are a prerequisite for further production operations. [1,2,3]

The paper deals with increasing the productivity of a welding line using industrial engineering methods and applications of lean manufacturing principles leading to lean production process and logistics. The process analysis of all manufacturing operations is the main indicator for batch production and revelation of bottlenecks which must constantly be eliminated. The paper points to the practical verification of acquired knowledge in the field of industrial engineering and subsequent applications in real operation in the automotive industry. $[4,5,6]$

The automotive industry accounts for approximately one quarter of the domestic industrial production, and every 23 seconds one car is produced in the Czech Republic. The main trends of car makers include pressure to cost reduction and increase in production efficiency. The automotive industry is a very turbulent environment. [7]

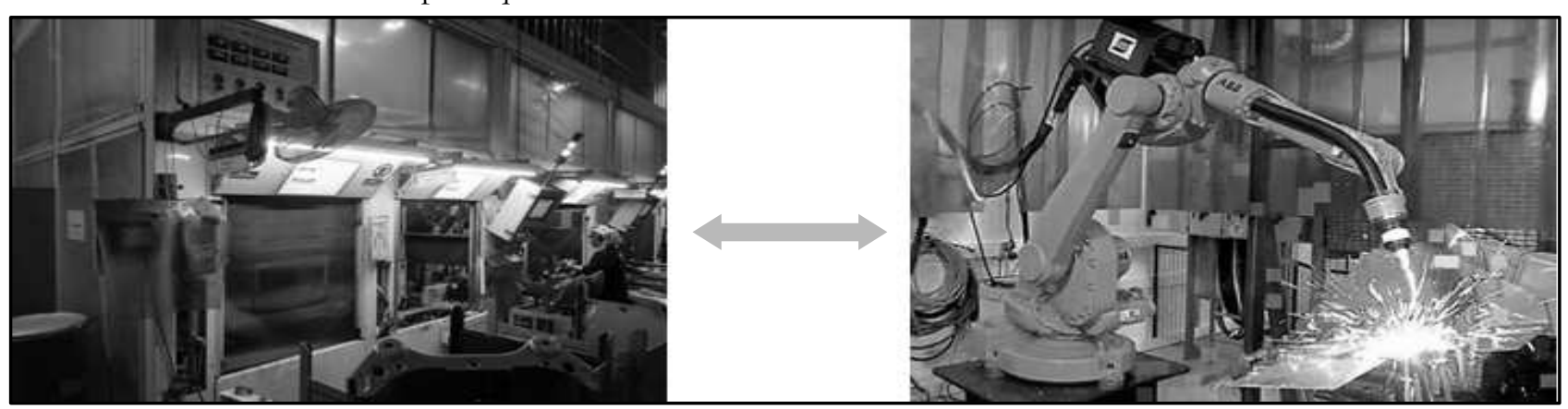

Fig. 1 Rear chassis welding line [7] 


\section{Analysis for bottlenecks identification}

The company in which the production line innovation was applied is engaged in the production of automotive parts. It relates to production of axles and their parts, fuel tanks, pedal modules, roof systems and also parts of car bodies. The main customers are two automotive companies for which parts to the individual model series are delivered. The chapter focuses on the analysis of the state of the original production line, which produces parts for the rear axle of a compact SUV. The table below (Tab. 1) shows all the products that are delivered to this type of car, including their technological production processes. $[2,7,8,9]$

Tab. 1 Overview of products and production processes [7]

\begin{tabular}{|l|l|}
\hline \multicolumn{1}{|c|}{ Products } & \multicolumn{1}{|c|}{ Production processes } \\
\hline Fuel tanks & $\begin{array}{l}\text { Welding, painting and } \\
\text { assembly }\end{array}$ \\
\hline $\begin{array}{l}\text { Front and rear chassis } \\
\text { parts }\end{array}$ & $\begin{array}{l}\text { Welding, painting, ma- } \\
\text { chining and assembly }\end{array}$ \\
\hline $\begin{array}{l}\text { Clutch gas and brake pe- } \\
\text { dals }\end{array}$ & $\begin{array}{l}\text { Welding, assembly and } \\
\text { testing }\end{array}$ \\
\hline
\end{tabular}

Welding shop is a key workplace within the whole company and deals mainly with the production of front and rear chassis parts. Here, steel pressed or machined parts are welded which are then joined together by arc welding with filler material in a protective atmosphere of an argon and CO2 mixture. Welding lines and spaces are equipped with OTC-Daihen and Nachi PLC robots. [10]

Welding rotary tables (Fig. 2) of two types are used on welding lines:

- hydraulic - rotation is controlled by hydraulics (compressed air), more prone to mechanical damage and often cause poor production

- electric - rotation is controlled by electrical components (electric motor). [3,7]

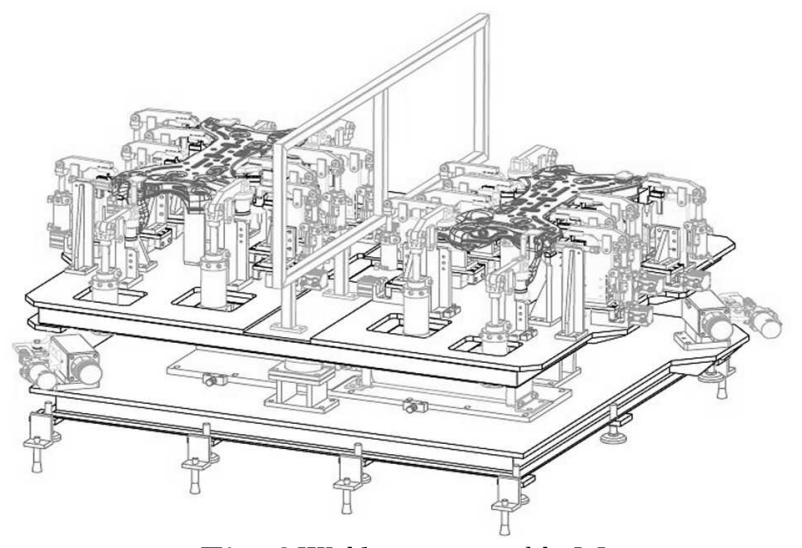

Fig. 2 Welding rotary table [7]

\subsection{Rear chassis welding line}

The welding rotary table, the operating principle of which is based on a hydraulic solution, forms part of the welding chassis line. The last welding space contains this rotary table and represents the bottleneck of the welding line this way. It was necessary to identify the bottleneck in more detail; the advantages and disadvantages of the hydraulic welding table are shown in the table below (Tab. 2). [2,8]

Tab. 2 Advantages and disadvantages of bydraulic welding table $[3,7]$

\begin{tabular}{|l|l|}
\hline \multicolumn{1}{|c|}{ Advantages (+) } & \multicolumn{1}{|c|}{ Disadvantages (-) } \\
\hline \multirow{2}{*}{$\begin{array}{l}\text { Used when space is limi- } \\
\text { ted }\end{array}$} & $\begin{array}{l}\text { Frequent cracking of } \\
\text { shafts due to table } \\
\text { weight }\end{array}$ \\
\cline { 2 - 2 } & High weight (2 tons) \\
\hline \multirow{4}{*}{$\begin{array}{l}\text { The operator loads the } \\
\text { material while welding } \\
\text { the product }\end{array}$} & $\begin{array}{l}\text { Rotation speed of the } \\
\text { table (high) - impact to } \\
\text { the stops }\end{array}$ \\
\cline { 2 - 2 } & $\begin{array}{l}\text { Changing the ideal posi- } \\
\text { tion of the table - wrong } \\
\text { positioning of welds }\end{array}$ \\
\hline
\end{tabular}

The welding line specializing in the production of components for rear axles consists of four welding spaces. These four spaces are connected and work simultaneously. Two operators are also involved in the operation, the first one operating the three welding spaces and the other focusing on the last space containing the welding rotary table. For an overview, the production line diagram is shown below (Fig. 3) and its detailed description of individual activities is included in the table (Tab. 3).

The line is situated in the rear part of the production hall together with other production lines, each welding space is a subline (marked with the letter "S"). Subline is the name for the subordinate production lines to the main ones. Their production is important in order to provide parts or material for the main production lines. If this subline does not produce the required amount of products, there is a risk of stopping the production of the main line, which can lead to non-compliance with the required standards and the subsequent stopping of the assembly line (or suspension at the customer). [7,11]

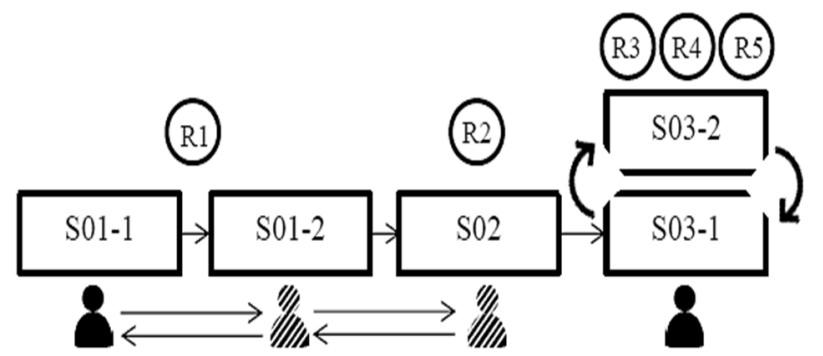

Fig. 3 Diagram of welding line of rear chassis parts [7] 
Tab. 3 Description of activities of individual operations during production [7]

\begin{tabular}{|c|l|}
\hline Welding space & \multicolumn{1}{c|}{ Description of activity } \\
\hline S01-1, S01-2 & $\begin{array}{l}\text { There are two welding spaces, the first (S01-1) for the production of the front parts and the } \\
\text { other (S01-2) for the production of the rear parts. The operator in S01-1 loads the moulded } \\
\text { part and the special hoop into the machine. The device clamps these parts and the operator } \\
\text { checks the correct position. After the inspection, the welding tarp comes out and the wel- } \\
\text { ding robot starts working. After the completion of the welding process, the operator pulls } \\
\text { out the part and checks its quality. The same procedure is then repeated in S01-2. }\end{array}$ \\
\hline S02 & $\begin{array}{l}\text { In S02, the parts from previous workplaces are connected. The operator inserts the part } \\
\text { from S01-1. After clamping, he inserts the part from S01-2 into the machine and the ma- } \\
\text { chine clamps this part. The parts then lock together and then the welding tarp comes out, } \\
\text { the welding robot starts welding. After welding, the operator checks the product quality and } \\
\text { passes it to the last welding space. }\end{array}$ \\
\hline S03-1, S03-2 & $\begin{array}{l}\text { In this space, the joined parts are reinforced. The operator inserts the connected part into } \\
\text { the device and then inserts the middle and side stiffeners. After clamping, the operator } \\
\text { checks the position of all parts and if everything is OK, the process can continue. The table } \\
\text { turns and moves the part to the welding robot area (three in total). After welding the } \\
\text { stiffeners, the table is rotated and the operator checks the product quality. The product is } \\
\text { placed in a cart and moved to the main rear axle production line. The procedure is shown } \\
\text { in the figure (Fig. 4). }\end{array}$ \\
\hline
\end{tabular}

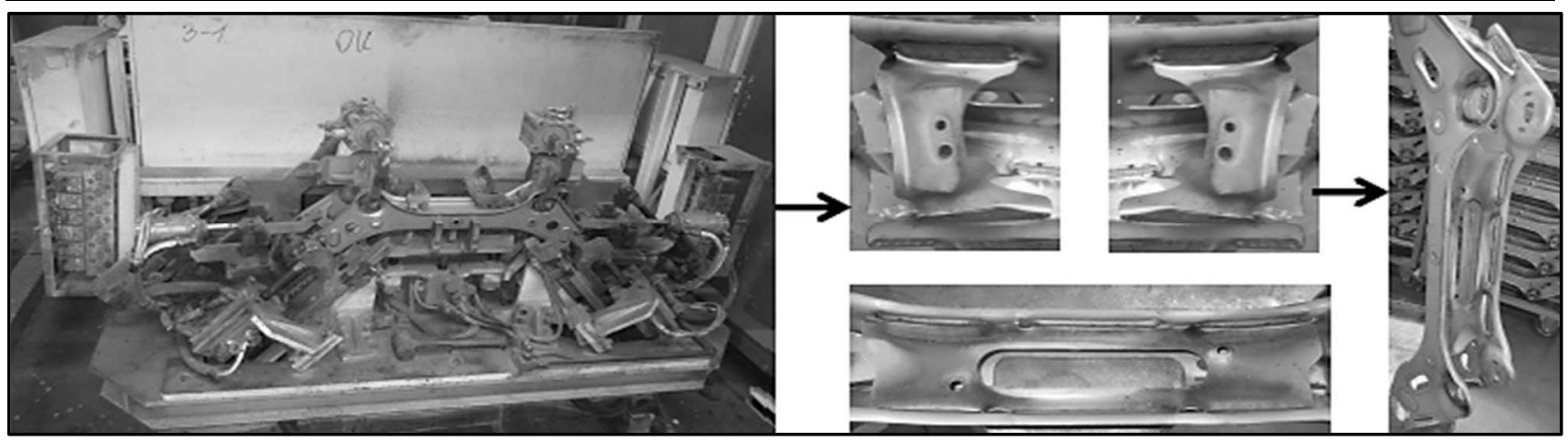

Fig. 4 Welding procedure in S03-1, S03-2 [7]

\subsection{Identification of bottlenecks}

The analysis of the current situation was followed by a precise characterization of the bottleneck in the production process, the place which is heavily loaded and needs to be accelerated - the production line is as fast as its bottleneck. The bottleneck identification lay in the cycle time method. First, the individual slots were measured during manufacture. Then the individual procedures performed by the worker or welding robot were defined, including the assignment of the duration of these operations. Finally, the individual operation times for a particular welding space were added up to determine the total cycle time for a particular welding space. $[7,12]$

After determining the cycle times for all spaces, the highest cycle time (i.e. the bottleneck) could be determined. Accordingly, the amount of products produced by this line during the working shift was determined. The cycle time of the individual welding spaces is explained in the table (Tab. 4) including the graph. Measurements were made during the production when no disturbances were reported. $[1,10]$

Tab. 4 Determination of cycle time of welding spaces of production line [7]

\begin{tabular}{|c|c|c|c|c|}
\hline \multirow{3}{*}{$\begin{array}{c}\begin{array}{c}\text { Welding } \\
\text { space }\end{array} \\
\text { S01-1 }\end{array}$} & \multicolumn{4}{|c|}{ Cycle time } \\
\hline & \multirow{2}{*}{$\begin{array}{c}\begin{array}{c}\text { Operator } \\
\text { [s] }\end{array} \\
18\end{array}$} & \multirow{2}{*}{$\begin{array}{c}\text { Machine } \\
\text { [s] }\end{array}$} & \multicolumn{2}{|c|}{ Total [s] } \\
\hline & & & 38 & 19 \\
\hline S01-2 & 12 & 22 & 34 & 17 \\
\hline S02 & 16 & 44 & \multicolumn{2}{|c|}{60} \\
\hline S03-1 & 25 & 4 & \multicolumn{2}{|c|}{29} \\
\hline S03-2 & 5 & 71 & \multicolumn{2}{|c|}{76} \\
\hline
\end{tabular}

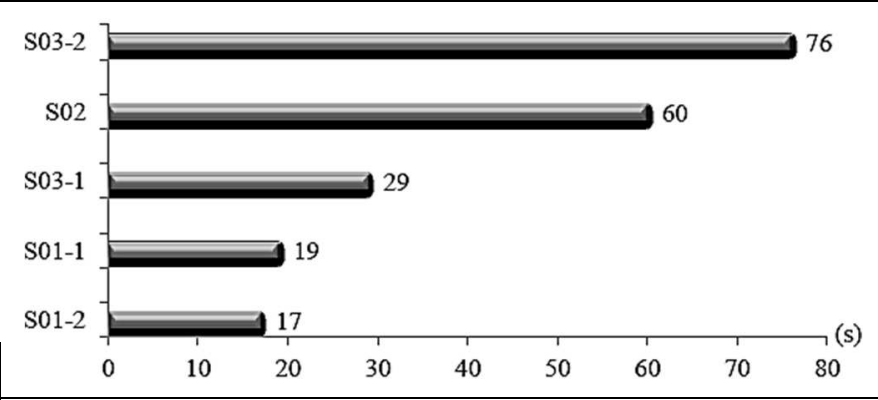


The table shows that the bottleneck of this production line is the welding space $\mathrm{S} 03-2$, which is equipped with a rotary table. Since the first welding space is doubled, this value is divided by two. The resulting cycle time is determined by the highest divided value, i.e. 19 seconds. Welding space S01-1 and S01-2 show different cycle time values. This may be caused by the operator's movement, his speed or welding time. Attention has been paid to acceleration of the SO3 welding space, the course of operations and time duration of SO3 is shown in the table (Tab. 5).

Tab. 5 Determination of the welding space cycle time S03-1,2 77

\begin{tabular}{|c|c|c|c|c|c|}
\hline \multirow{2}{*}{ Welding space } & \multirow{2}{*}{ Order } & \multirow{2}{*}{ Operation } & \multicolumn{3}{|c|}{ Cycle time } \\
\hline & & & Operator [s] & Machine [s] & Total [s] \\
\hline \multirow{3}{*}{ S03-1 } & 1 & $\begin{array}{l}\text { Inserting parts into the ma- } \\
\text { chine }\end{array}$ & 15 & $\begin{array}{lllll}2 & 1\end{array}$ & \multirow{3}{*}{29} \\
\hline & 2 & Automatic fastening of parts & - & 4 & \\
\hline & 3 & Check of fit & 10 & - & \\
\hline \multirow{7}{*}{ S03-2 } & 1 & Table rotation & - & 8 & \multirow{7}{*}{76} \\
\hline & \multirow{3}{*}{2} & Welding (robot R3) & - & 53 & \\
\hline & & Welding (robot R4) & - & 42 & \\
\hline & & Welding (robot R5) & - & 53 & \\
\hline & 3 & Automatic parts release & - & 2 & \\
\hline & 4 & Table rotation & - & 8 & \\
\hline & 5 & Loading the cart & 5 & - & \\
\hline
\end{tabular}

From the table we can see that the welding time, namely the welding robots R3 and R5, took the highest process time. This was caused mainly by splitting of individual welds; these robots welded more welds than the R4 welding robot. To determine the total cycle time, the value with the highest welding time is always taken. The bottleneck of the production line was the S03 welding space. [7,13]

\section{Innovation of the production line}

Within the analysis, it was determined that the S03 welding space will be the target of the conversion. The conversion plan contained a total of two designs for the new welding production line, neither of which included the possibility of leaving a welding rotary table. Furthermore, three workplace ergonomics designs were made and attention was also paid to the number and selection of welding robots to be included in the new production line. All these plans were described and their pros and cons evaluated. Subsequently, the final plan for the conversion of this welding production line was chosen, which is described in this chapter.

\subsection{Design of production line}

The conversion was carried out according to the second design option, which was based on the addition of one welding robot and welding space (Fig. 5). Unlike the original production line, this upgrade is more efficient in preventing the production of poor quality products by removing the welding rotary table. This conversion design does not eliminate the creation of a new bottleneck, but prevents the difference between the cycle time of the newly formed bottleneck and other welding spaces to be so significant. [7]

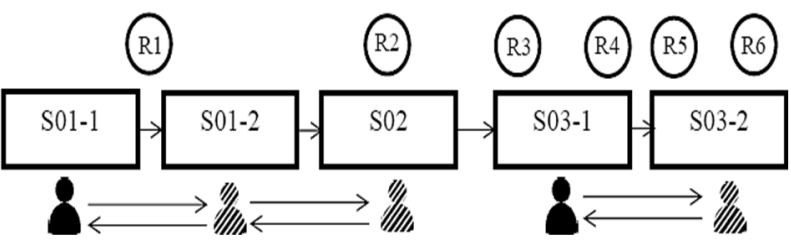

Fig. 5 Scheme of implemented welding line [7]

The goal was to achieve an even distribution of cycle times on the individual welding spaces. According to this optimization, the production line is operated by two workers who switch between the individual welding spaces. Concearning financial and time demands, this version of the conversion was the most advantageous solution. The advantages and disadvantages of the innovation are shown in the table (Tab. 6).

Tab. 6 Advantages and disadvantages of the implemented welding line 77

\begin{tabular}{|l|l|}
\hline \multicolumn{1}{|c|}{ Advantages (+) } & \multicolumn{1}{c|}{ Disadvantages (-) } \\
\hline $\begin{array}{l}\text { Lower financial de- } \\
\text { mands }\end{array}$ & $\begin{array}{l}\text { Slower cycle time when } \\
\text { compared with the first } \\
\text { design option }\end{array}$ \\
\hline Saving space & $\begin{array}{l}\text { Slower compliance with } \\
\text { standards when compa- } \\
\text { red with the first design } \\
\text { time }\end{array}$ \\
\hline Option
\end{tabular}

\subsection{Ergonomics of workplace}

Ergonomics is an integral part of the work environment. It is essential that the workplaces be adequately adapted to the work of the operator. The basic goal is to eliminate unnecessary movements, height of 
the workbench, etc. All these findings and characteristics were taken into account when converting the production line. A total of three types of ergonomic designs were compiled and the chosen option is described in this part of the chapter.

The space where the production line is located was a significant limitation. Further expansion of the space was impossible because of the location of the way to the warehouse next to the production line. A collision with the forklift could occur. The production line is located in the rear part of the production hall, behind which there is a wall and the whole area around this line is built up with other workplaces. The original and new ergonomic layout of the production line is shown in the figure (Fig. 6). [7]

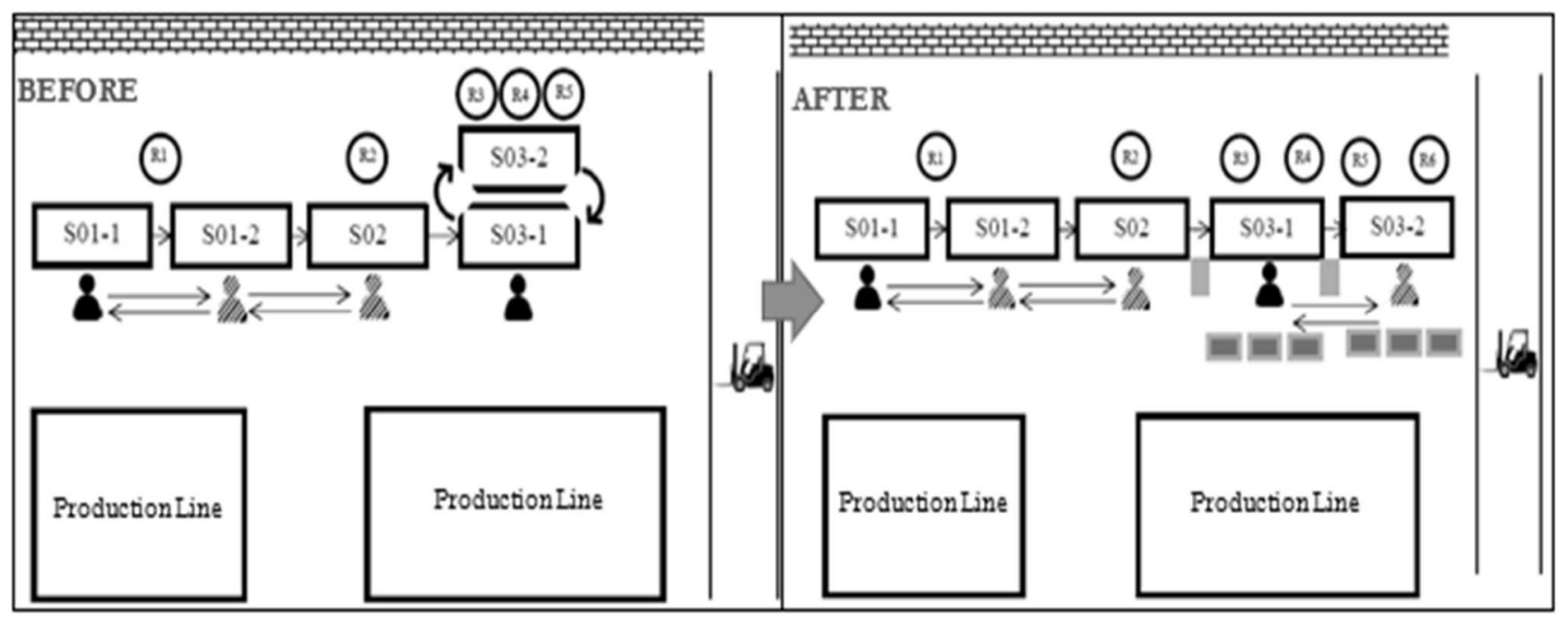

Fig. 6 Original and new ergonomic layout of the production line [7]

The new design concentrated on easy access to the new welding space, on the layout of the final carts and auxiliary storage tables marked in the diagram. The new welding space was situated next to the original welding line, which has the shape of a straight line. In comparison with other designs, this layout increases the time for the worker to move between the individual welding space. The advantages and disadvantages of the design are shown in the table (Tab. 7). [7]

Tab. 7 Advantages and disadvantaged of the new ergonomic layout 77$]$

\begin{tabular}{|l|l|}
\hline \multicolumn{1}{|c|}{ Advantages (+) } & \multicolumn{1}{|c|}{ Disadvantages (-) } \\
\cline { 1 - 1 } Space requirements & \\
\cline { 1 - 1 } Material supply & $\begin{array}{l}\text { Movement of the wor- } \\
\text { ker } \\
\text { Storage of work in pro- } \\
\text { gress (auxiliary tables) }\end{array}$ \\
\cline { 1 - 1 } Space for final carts & \\
\hline
\end{tabular}

\subsection{Selection of welding robot}

After layout and ergonomics of the workplace, it was important to choose a welding robot that would meet all the requirements. The multi-criterial decisionmaking method was chosen to select the optimal robot. Four options of welding robots from different manufacturers with similar parameters were compared. An important parameter for selecting these four robots was, for example, the working range. This is the smallest and greatest value in which a robot is able to do its job. Another criterion was the speed of movement of the robot, which relates to efficiency, but it should not be forgotten that the speed also relates to the resulting quality of the weld and thus the resulting product. [7,9]

\section{Multi-criterial decision-making}

Within the multi-criterial decision-making, the Weighted Partial Order Method was used. The results were confirmed by the basic method. An important element for selecting an optimal robot is also the selection of significant criteria by which the selection was made, in addition to specifying its properties. The criteria were consulted in advance in the company and a range of values was defined to meet the requirements. A total of five experts participated in the evaluation of these criteria, half of them from the maintenance department and the other half from the production department. The evaluation of the optimal robot, an overview of the criteria and other types of robots from which it was selected can be seen in the table below (Tab. 8). [7]

From the table we can see that the Weighted Partial Order Method has identified Daihen FD-V6 as the optimal welding robot for the innovation of this production line (Fig. 7). This welding robot has not only the best height or radius of the working range, but also the maximum load capacity of the upper arm and the accuracy of position repetition. 
Tab. 8 Evaluation of results 77

\begin{tabular}{|c|c|c|c|c|c|c|c|c|}
\hline & Price & Weight & $\begin{array}{c}\text { Criterion } \\
\text { Option }\end{array}$ & $\begin{array}{c}\text { Accuracy } \\
\text { of position } \\
\text { repetition }\end{array}$ & $\begin{array}{c}\text { Working } \\
\text { range }\end{array}$ & $\begin{array}{c}\text { Maximum } \\
\text { load } \\
\text { height } \\
\text { capacity of } \\
\text { the upper } \\
\text { arm } \\
+\end{array}$ & $\mathbf{S j}$ & $\mathbf{V j}$ \\
\hline $\begin{array}{c}\text { OTC } \\
\text { Daihen } \\
\text { FD-V6 }\end{array}$ & 3.32 & 2.19 & 0.94 & 0.9 & 0.79 & 1.62 & 9.76 & $\mathbf{1}$ \\
\hline Nachi NV06 & 2.49 & 2.92 & 0.94 & 1.8 & 2.37 & 1.62 & 12.14 & $\mathbf{3}$ \\
\hline $\begin{array}{c}\text { Fanuc arc } \\
\text { mate 100iB }\end{array}$ & 1.66 & 1.46 & 1.88 & 2.7 & 1.58 & 0.81 & 10.09 & $\mathbf{2}$ \\
\hline $\begin{array}{c}\text { Yaskawa } \\
\text { Motoman } \\
\text { UP6 }\end{array}$ & 0.83 & 0.73 & 1.88 & 3.6 & 1.58 & 1.62 & 22.23 & 4 \\
\hline Bj & 0.830 & 0.730 & 0.940 & 0.900 & 0.790 & 0.810 & & \\
\hline
\end{tabular}
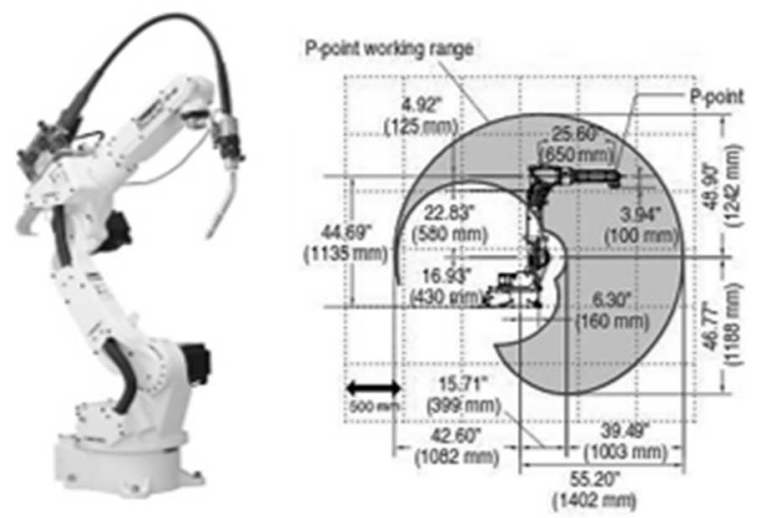

Fig. 7 Welding robot OTC Daiben FD-V6 and its welding range [7]

\section{Evaluation of optimization}

The conversion was carried out according to the design, which was based on the addition of one welding robot. The financial aspects of the conversion, space and efficiency were also important. The speed of conversion, which is acceptable under this proposal, also played a role in the decision-making process. After implementation, the cycle time of this welding production line was measured again. The result of the measurement is in compliance with the proposed optimization and it can be stated that the conversion was beneficial for the company. More detailed information on a given cycle time measurement is provided in this chapter.

The main goal of the welding line optimization was to reduce cycle times, according to calculations the upgraded line should achieve these goals. However, it was necessary to verify these cycle calculations under full line operation. Measurements were made by recording individual operations with the camera. The records were then used to determine the individual work steps and their times leading to the production of the final product. The cycle times of the individual welding spaces after the upgrade, including the graph, are included in the table (Tab. 9). [11,14]

Tab. 9 Cycle time determination of production line welding spaces after upgrade 77

\begin{tabular}{|c|c|c|c|c|}
\hline \multirow{2}{*}{$\begin{array}{c}\text { Welding } \\
\text { space }\end{array}$} & \multicolumn{4}{|c|}{ Cycle time } \\
\cline { 2 - 5 } & $\begin{array}{c}\text { Operator } \\
{[\mathrm{s}]}\end{array}$ & $\begin{array}{c}\text { Machine } \\
{[\mathbf{s}]}\end{array}$ & \multicolumn{2}{|c|}{ Total [s] } \\
\hline S01-1 & 14 & 20 & $\mathbf{3 4}$ & $\mathbf{1 7}$ \\
\hline S01-2 & 14 & 20 & $\mathbf{3 4}$ & $\mathbf{1 7}$ \\
\hline S02 & 10 & 44 & \multicolumn{2}{|c|}{$\mathbf{5 4}$} \\
\hline S03-1 & 23 & 69 & $\mathbf{9 2}$ & $\mathbf{4 6}$ \\
\hline S03-2 & 23 & 69 & $\mathbf{9 2}$ & $\mathbf{4 6}$ \\
\hline
\end{tabular}

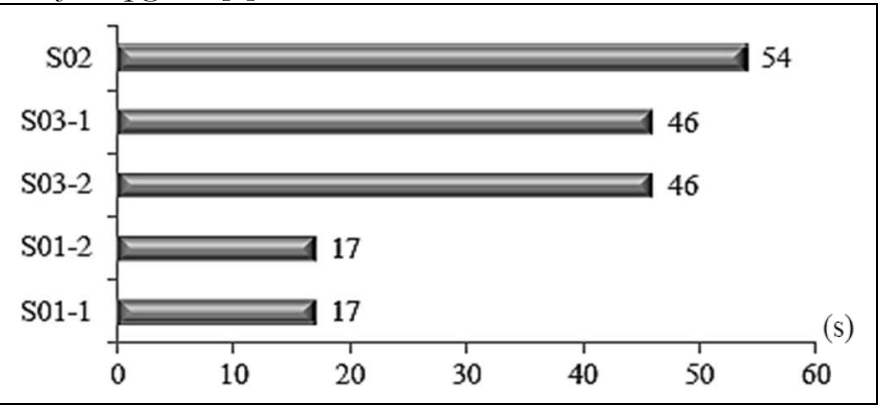

The third welding space has a total time of $92 \mathrm{sec}-$ onds, since it is doubled, it is necessary to divide this value by two. Thus, the resulting cycle time is $46 \mathrm{sec}-$ onds. The measurement results for the individual

welding space indicate that the bottleneck is no longer at the third, but at the second position. Furthermore, an even distribution of the cycle time between the individual welding spaces can be read. 
The following table summarizes the operation and time duration of the welding space after the upgrade (Tab. 10). It can be seen that the greatest time is in the welding process. However, if it is necessary to ensure a quality weld, this time cannot be shortened below the acceptable limit. The measurement shows the difference in welding times between individual spaces. This difference was caused by the individual programming of the welding robots. [7,14]

Tab. 10 Determination of cycle time of welding space S03-1,2 after upgrade [7]

\begin{tabular}{|c|c|c|c|c|c|}
\hline \multirow{2}{*}{$\begin{array}{l}\text { Welding } \\
\text { space }\end{array}$} & \multirow{2}{*}{ Order } & \multirow{2}{*}{ Operation } & \multicolumn{3}{|c|}{ Cycle time } \\
\hline & & & Operator [s] & Machine [s] & Total [s] \\
\hline \multirow{10}{*}{ S03-1 } & 1 & $\begin{array}{l}\text { Inserting parts into the ma- } \\
\text { chine }\end{array}$ & 12 & - & \multirow{10}{*}{92} \\
\hline & 2 & Automatic fastening of parts & - & 4 & \\
\hline & 3 & Lowering the protective film & - & 2 & \\
\hline & \multirow{2}{*}{4} & Welding (robot R3 part I) & - & 33 & \\
\hline & & Welding (robot R4 part I) & - & 17 & \\
\hline & \multirow{2}{*}{5} & Welding (robot R3 part II) & - & 16 & \\
\hline & & Welding (robot R4 part II) & - & 28 & \\
\hline & 6 & $\begin{array}{c}\text { Raising the film and releasing } \\
\text { the part }\end{array}$ & - & 2 & \\
\hline & 7 & Quality control & 7 & - & \\
\hline & 8 & Storage in cart & 4 & - & \\
\hline \multirow{10}{*}{ S03-2 } & 1 & $\begin{array}{l}\text { Inserting parts into the ma- } \\
\text { chine }\end{array}$ & 12 & - & \multirow{10}{*}{92} \\
\hline & 2 & Automatic fastening of parts & - & 3 & \\
\hline & 3 & Lowering the protective film & - & 2 & \\
\hline & \multirow{2}{*}{4} & Welding (robot R5 part I) & - & 33 & \\
\hline & & Welding (robot R6 part I) & - & 17 & \\
\hline & \multirow{2}{*}{5} & Welding (robot R5 part II) & - & 16 & \\
\hline & & Welding (robot R6 part II) & - & 30 & \\
\hline & 6 & $\begin{array}{c}\text { Raising the film and releasing } \\
\text { the part }\end{array}$ & - & 2 & \\
\hline & 7 & Quality control & 7 & - & \\
\hline & 8 & Storage in cart & 3 & - & \\
\hline
\end{tabular}

The productivity of the production before and after the upgrade of this production line including a graph showing the comparison of the cycle time for the production of components is included in the table (Tab. 11). After the innovation, the bottleneck on the production line was detected in the second welding space, but this value was in conformity with current requirements. An important value is also the number of pieces produced per shift. It is obvious that the upgraded production line is much more efficient than the original one.

Tab. 11 Productivity and gycle times before and after upgrade [7]

\begin{tabular}{|l|c|c|}
\hline \multicolumn{1}{|c|}{ Value } & $\begin{array}{c}\text { Before } \\
\text { upgrade }\end{array}$ & $\begin{array}{c}\text { After up- } \\
\text { grade }\end{array}$ \\
\hline $\begin{array}{l}\text { Number of pieces } \\
\text { per shift [pcs/shift] }\end{array}$ & 47 & 66 \\
\hline $\begin{array}{l}\text { Total cycle time re- } \\
\text { duction [s] }\end{array}$ & \multicolumn{2}{|c|}{13} \\
\hline $\begin{array}{l}\text { Production cycle ti- } \\
\text { mes }\end{array}$ & $=$ \\
\hline
\end{tabular}

\subsection{Benefits for practice}

The optimization of the SUV rear axle production line has brought many benefits to the company. The

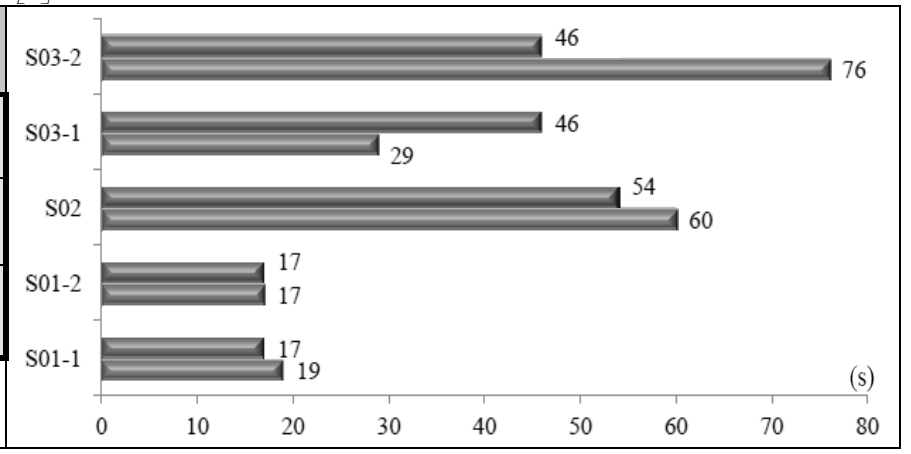

cycle time was reduced, the working environment and product quality were improved, and the efficiency and productivity of this line were improved. The original rotary table was dismantled and its parts were left for 
possible repairs of other rotary tables in the company. The overall design of the production line and the list of benefits of the upgrade are included in the table (Tab. 12).

Tab. 12 Benefits of an upgraded production line [7]

\begin{tabular}{|l|l|}
\hline Benefits of an upgraded production line \\
\hline Reduced cycle time \\
\hline Increase in productivity & Increase in efficiency \\
\hline Improved product quality & \\
\hline Improved working environment & \\
\hline Better usability of workers & \\
\hline Auxiliary storage tables & \\
\hline
\end{tabular}

\section{Conclusion}

The goal of this paper was to optimize and ensure the efficiency of the welding production line. Any improvement should be beneficial for the company, i.e. efficient. The upgraded welding line has prevented poor quality production and increased the number of products produced per shift, so it has better cycle time. Improvements to the working environment were made too, which increased the satisfaction of workers on this line. The paper shows that the main problem of poor production was the welding rotary table, which was removed during the innovation. Before the conversion itself, designs were made, both in terms of ergonomics and innovation for the selection of a suitable welding robot. After a thorough evaluation of all options, the final design was chosen, according to which the entire conversion was carried out. The first products were subjected to quality analysis and the line was considered operational. Therefore, the upgrade met the requirements, be it optimization or company benefits.

The automotive industry is constantly undergoing a number of changes, not only in terms of technological innovations on individual vehicles, but also in production processes. It is therefore essential to keep up with the competition and try to come up with new and better innovations, even within the requirements for Industry 4.0.

\section{References}

[1] SHAN H., YUAN Y., ZHANG Y., LI L., WANG C. (2019). Lean, Simulation and Optimization: The Case of Steering Knuckle Arm Production Line. In: IEEE 2018: International Conference on Industrial Engineering and Engineering Management, pp. 1386 - 1390. IEEM 2017. ISSN 2157361, ISBN 978-153866786-6

[2] MICHELS A.S., LOPES T.C., SIKORA C.G.S., MAGATAO L. (2018). The Robotic
Assembly Line Design (RALD) problem: Model and case studies with practical extensions. In. Computers and Industrial Engineering, Vol. 120, pp. 320 - 333. Elsevier Ltd. ISSN 03608352

[3] OMAR M.A. (2011). The Automotive Body Manufacturing Systems and Processes, 372 p. John Wiley and Sons. ISBN 978-047097633-3

[4] KABELE, P., EDL, M. (2020). Increasing the efficiency of the production process due to using of industrial engineering. In. Lecture Notes in Mechanical Engineering, pp. 126 - 137. Pleiades Publishing. ISSN 21954356

[5] ZHOU B., WU Q. (2018). A novel optimal method of robotic weld assembly line balancing problems with changeover times: a case study. In. Assembly Automation, Vol. 38, Issue 4, pp. 376 - 386. Emerald Group Publishing Ltd. ISSN 01445154

[6] URIARTE A.G., NG A.H.C., ZUNIGA E.R., MORIS M.U. (2018). Improving the material flow of a manufacturing company via lean, simulation and optimization. In: IEEE 2017: International Conference on Industrial Engineering and Engineering Management, pp. 1245 - 1250. IEEM 2017. ISSN 21573611

[7] BAJGER, J. (2018) Production Improvement and Ensuring Efficiency of the Production Line: Master Thesis. Ostrava: VŠB - Technical University of Ostrava. Faculty of Mechanical Engineering. Department of Mechanical Technology, $75 \mathrm{p}$. Thesis head: Schindlerová, V.

[8] MOON D.H., CHO H.I., KIM H.S., SUNWOO H., JUNG J.Y. (2006). A case study of the body shop design in an automotive factory using 3D simulation. In. International Journal of Production Research, pp. 4121 - 4135. IFPR. ISSN 00207543 
[9] SCHINDLEROVÁ, V., ŠAJDLEROVÁ I. (2017) Influence of tool wear on material flow. In. Advances in science and technology research journal, Vol. 11, No.1, pp. 161-165. Lublin University of Technology, Poland. ISSN 2299-8624

[10] LOPES T.C., SIKORA C.G.S., MOLINA R.G., SCHIBELBAIN D., RODRIGUES L.C.A., MAGATAO L. (2017). In. European Journal of Operational Research, pp. 1033 - 1048. Elsevier BV. ISSN 03772217

[11] KREJCI, L., SCHINDLEROVA, V., BUCKO, M., HLAVATY, I., MICIAN, M. (2019). The Application of PFMEA for Roller Bearings Production. In. Manufacturing Technology, pp. 439 - 445. J. E. Purkyne University in Usti nad Labem. ISSN 12132489
[12] LEHOCKA, D., HLAVATY, I., HLOCH, S. Rationalization of Material Flow in Production of Semitrailer Frame for Automotive Industry. In: Tehnicki Vjesnik-Technical Gazette, Vol. 23, No. 4, pp. 1215 - 1220. ISSN 1330-3651 (Print), ISSN 1848-6339 (Online)

[13] DAEINABI, K., TESHNEHLAB M. (2007). Industrial Arc Welding Robot Defect Tracking System in Automotive Industry. In: IEEE 2007: International Conference on Mechatronics and Automation, pp. 3937 - 3941. ICMA 2007. ISBN 1424408288; 978-142440828-3

[14] KREJCI, L., SCHINDLEROVA, V., BUCKO, M., HLAVATY, I. (2018). Application of a process FMEA for the welding. In: Metal 2018: 27th International Conference on Metallurgy and Materials, pp. 1145 - 1151, Ostrava: TANGER. ISBN 978-80-87294-84-0 